infections with streptococci and staphylococci, and the finding in 1941 that it could save patients from infections that would previously have been regarded as fatal.

The results obtained at Oxford transformed penicillin from a biological curiosity into a substance with great potential in medicine. A letter from Almroth Wright to The Times, in which he placed a laurel wreath on Fleming's brow, was followed by a flood of misleading publicity. Gwyn Macfarlane attempts to throw light on how it happened that Fleming was credited with a vision he did not have and even with work he had not done, while the discovery at Oxford, if mentioned at all, was presented as a minor development. It is clear that Florey had no wish for notoriety when so little penicillin was available and turned journalists away. As to what occurred at St Mary's the author can only surmise, but he points out that the Medical School had a history of poverty, and consequently of fund-raising, and that its Dean, Lord Moran, numbered Lord Beaverbrook (no stranger to publicity) among his influential friends.

Fleming himself made no exaggerated claims, although he acquiesced in what was happening and occasionally insinuated that the short-comings of others were responsible for his failure to exploit his discovery. Towards the end of the book we have an entertaining account of the effect of his rise to fame on his later life. Innumerable invitations, often involving long travel and coupled with scientific and social programmes that would have daunted many a younger man, were accepted without hesitation. But he received the praises of the crowds with becoming modesty and certainly never succumbed to folie de grandeur.

The main reason for concern about the Fleming myth was the possibility that it would permanently falsify the history of a dramatic medical advance. It had little influence on the judgement of the scientific establishment. Although the first clinical trial made it likely that penicillin's contribution to medicine would be immense, the work that had brought this about had made no comparable contribution to science. Florey wrote "The almost miraculous properties of penicillin should not blind us to the fact that the work carried out at St Mary's Hospital, London, and at Oxford introduced no new chemical or biological principles. The results, however, were new and the effects on medicine widespread". No one could have foreseen, in 1941, the chemical and biological developments which were to give the $\beta$-lactam antibiotics a scientific interest for a further forty years and continue to do so today. But this story lies outside the scope of Gwyn Macfarlane's book.

Sir Edward Abraham is Emeritus Professor of Chemical Pathology in the University of Oxford.

\section{Arms across the}

\section{waves}

\section{Laurence Martin}

The Independent Nuclear State: The United States, Britain and the Military Atom.

By John Simpson.

St Martin's Press, New York/Macmillan

Press, London: 1984. Pp.340. \$30, £25.

A KINDLY angel must have supervised the gestation of Dr Simpson's enterprising book, for he begins by explaining that he intended to write on a different subject altogether and that subsequent changes of plan have greatly delayed its completion. The result is that the book emerges at a most timely moment in both the politics and the historiography of British nuclear forces: politically because of the current and continuing debate over the British acquisition of Trident $I I$, and historiographically because a great deal of hitherto highly secret information is beginning to appear in the United States. Indeed it is one of the few and unavoidable limitations of this book that already it needs updating by reference to recent disclosures. So much more closed is the British defence establishment than the American, however, that this new information affects the context rather than the substance of the British story, and Dr Simpson's heavily documented account is likely to remain standard and invaluable for some years to come.

Scientifically competent readers will doubtless take particular interest in the author's effort to put precise numbers on the scale of British military nuclear production, by means that he himself admits to be crude and disputable. For those with a more general concern for the strategic and political implications of the British nuclear force, it is instructive to note that the current generally accepted "force loading" of the British submarine strategic force of about 200 warheads, is exactly the goal set in 1948 for achievement in 1960. This may say something about the stability of British conceptions of an adequate "assured destruction" capability, especially if we assume some rough correlation between the off-station factor in the submarine force and the likely attrition of its airborne predecessor. Whereas, however, the 1948 projection was conceived to be about half the American capability, today's British force is eclipsed in scale by that of the United States. The record of the British nuclear effort is, indeed, one of being steadily overtaken, though running a very game race. In 1941 Britain was probably the leader; by the time its national programme approached the point of acquisition of weapons, a decade later, Britain was already trailing the Soviet Union and about to become the world's first "Nth nuclear power"'
Dr Simpson's book, like Professor Margaret Gowing's official histories of the very early years, affords intriguing glimpses of mixed and often conflicting reasoning that has led successive British governments of both political parties to persist in a game in which the odds are uneven but in which not even the outsiders are negligible. The game is not made easier by continual changes in the rules. At the beginning the problem was to get the bomb; by the 1960 s the trick was to deliver it. At the outset having the bomb was thought to be more important than knowing what it was for. In 1947 the Foreign Secretary, Ernest Bevin, was content merely to argue that Britain "could not afford to acquiesce in an American monopoly in this new development". When, in 1948, the RAF specified a force capable of attacking 59 Soviet cities - even though many members of the Labour Cabinet would not accept that the Soviet Union was an enemy, a scruple the Berlin blockade and Czech coup were to remove - policy was still concerned with tactics rather than strategy. Only in 1952, when the British Chiefs of Staff devised and later sold to Churchill when restored to power a "grand strategy" based on deterrence by nuclear retaliation, could it be said that the expensive and secret weapon programme was harnessed to a strategic theory - albeit a debatable one.

It has long been known that the incoming Eisenhower Administration drew some support from the British strategic theory in evolving its own doctrine of Massive Retaliation. The whole British story is, of course, intimately bound up with the United States. The relationship was and is a complex one, and the motives, principles and prejudices of so many different layers of the pluralistic American machine politicians, military and scientists - made it difficult for the United States to pursue a consistent policy.

What the British needed from the United States - help in reducing costs - was rather simpler, and they were not without levers: among them their undoubted skill and know-how, even if those of the junior partner, the goodwill of past co-operation, and such legal holds on the United States as the Quebec agreement of 1942 requiring British consent for American use of nuclear weapons and agreed rights to a share in scarce uranium supplies from the Congo. Less tangible but nonetheless effective was the power Britain paradoxically enjoyed by being the weaker partner in an enterprise - the containment of the Soviet Union - of great importance to the United States. Merely by implication - often genuinely without any intention of doing so - Britain could threaten to divert its resources from supplying the conventional strength NATO needed, could show signs of paying a political price, perhaps even a price in nuclear co-operation, to win a French welcome to the European Community, or could obstruct an arms control initiative dear to America. 
In the case of arms control, as in several other aspects of policy, Dr Simpson's detailed account of British policy makes clear how often things were not what they seemed, how often apparent virtue masked more selfish motives, and how good causes produced unanticipated effects. This was particularly clear in the 1950s with initiatives for "Atoms for Peace", for a test ban, and for a cut-off of fissile material production. As keen as the Eisenhower Administration was on impeding the Soviet erosion of American nuclear superiority and on discouraging the French and Chinese nuclear programmes, the British were still on the wrong side of the line so far as actual achievement of their own stockpile was concerned, particularly of thermonuclear weapons. They were able to use their obstructive potential to win help in accelerating their programme through the 1958 amendments to the MacMahon Act. As a precaution Britain had also accelerated its plutonium output, however, and once American assistance led to more economical warhead designs, was able to barter plutonium for further assistance. All quite useful, perhaps, but not what was originally intended and rather remote from the issues with which political debate in either country was ostensibly concerned.

A better known paradox of the British nuclear relationship with the United States is illuminated by Dr Simpson's characterization of the roles played by Britain's two leading political parties. As Ernest Bevin's remark quoted earlier reminds us, the Labour Party, presumably because of a latent suspicion of the United States, was not only the founder of the independent British nuclear programme, but the more insistent that it should be independent. The first British tests were conducted in Australia rather than, as might have been possible and cheaper, in the United States, chiefly because Clement Attlee was unwilling to become dependent on the Americans. Churchill, by contrast, was much more inclined to see the nuclear programme as a tool in strengthening Anglo-American relations, even at the price of some loss of independence. It was Macmillan who based British nuclear power on an American missile but Labour Governments under Harold Wilson and James Callaghan which

\section{Journal reviews 1984}

The next review supplement to appear in Nature will be the New Journals Review, on 27 September. Criteria for journals to be considered for review are:

(i) the first number appeared, or the journal was re-titled, between June 1982 and May 1983 (these time limits allow for the publication of several issues of a journal, on which a reasonable judgement may be based);

(ii) the journal appears at least three times a year;

(iii) the main language used is English.

During May publishers will be requested to submit four issues of appropriate publications for review. secretly completed the new re-entry vehicle Chevaline and reacted to a rising tide of American anti-proliferationism, especially under President Carter, by establishing a national source of tritium and reopening stages of the British enrichment plant. Once President Reagan changed the rhetoric, it was the subsequent Thatcher Government that slowed down this process and purchased yet another American missile.

In the last and inevitably most speculative part of his book, Dr Simpson considers the future of this trans-Atlantic nuclear relationship and of the British force within it. Reluctantly he comes to the conclusion that Britain could not readily become a nonnuclear power even if it wanted to do so; it is too impregnated with knowledge and capability. This observation constitutes yet another recognition of how elusive the distinction between nuclear and nonnuclear powers becomes as understanding of nuclear engineering proliferates. Nuclear weapons play their part chiefly as latent factors in political relations. Hence the importance attached to the status of Israel and India as virtual nuclear powers or to Argentina and Pakistan as nearlynuclear powers. Somewhat the same relativism is appropriate in contemplating the pervading question raised by Dr Simpson's book: just how independent is the British deterrent? The brief reply is that there is no simple answer to such a question; most of the time derivative weapons, like potential weapons and suspected weapons, can all play some part in the political balances.

Nevertheless the state of Anglo-American nuclear relations is a major influence on the tone of the alliance, and one reason Dr Simpson's book is timely is that several current trends could radically alter that relationship in the next few years. In Britain, the chief source of instability lies in the Labour Party's move outside the bipartisan consensus that has prevailed since the 1940s. In the United States, if the mood represented by Dr Henry Kissinger's recent demand that the Europeans should show greater self-reliance in defence gains much ground, it must inevitably become entangled with Mr Robert McNamara's parallel insistence that the United States offer less by way of nuclear guarantees to Europe. The relatively relaxed British attitude to the question of dependency or independence has flourished under the shade of a sturdy American nuclear umbrella. It is too early to say what the outcome would be if the web of mutual Anglo-American understanding in nuclear matters began to unravel. The story told by Dr Simpson does suggest one firm prediction, however, and that is that the result is highly unlikely to be exactly what anyone intended.

Laurence Martin, Vice-Chancellor of the University of Newcastle upon Tyne, was Professor of War Studies at the University of London from 1968 to 1977.

\section{Binary weapons: the monster is loose}

John Erickson

No Fire No Thunder: The Threat of

Chemical and Biological Weapons.

By Seán Murphy, Alastair Hay and

Steven Rose.

Pluto Press: 1984. Pp.145. Pbk £3.95.

MANY years ago we bravely faced the "bomber gap". Latterly we have been strenuously persuaded of the "missile gap" in its various configurations, not to mention the attendant "window of vulnerability" - the metaphors tend to become a little mixed - but we are back again with what is currently advertised as the "gas gap". The deterrent, or one component of it, is again threatened, or so Richard L. Wagner, assistant to the US Secretary of Defence, asserts. "The United States currently lacks a deterrent to a Soviet chemical weapons attack in Europe", since there is no counterpart to match Soviet capability to lay down a persistent gas screen beyond the 10 kilometre artillery range.

Soviet forces, equipped with binary weapons and " 14 or 15 chemical weapons capable of being delivered at long ranges", can deliver persistent agents deep within NATO's rear, well beyond artillery range, engulfing logistics, supply centres, airfields, and command and control links. At such ranges NATO forces must fight "buttoned up", encumbered with protective gear, while Soviet rear areas would be virtually immune: air delivery of chemical agents by NATO at present involves pilots flying what amounts to suicide missions, coming in low and on a predictable course, only to deliver antiquated munitions as a spray which disperses all too quickly. Hence the "gas gap", and weapons such as BIGEYE (a spray bomb for F-111 aircraft) as well as plans to develop some 15 types of munitions in the binary role.

The subject of chemical and biological warfare (CBW), while having its own arcane vocabulary, also exudes singular repulsiveness. "Binary weapons" sound almost clinically clean, shut away from this house of horrors, but the monster is loose, striking most recently in the Iran-Iraq war where mustard and nerve gases have been used. This alone would give No Fire No Thunder not only great timeliness but also added value as a guide to this particular type of warfare, BIGEYE included as well as those reports from South-east Asia and Afghanistan. In the latter context, operations in Afghanistan, the reader can usefully turn to an article by Dr E. M. Spiers, "Gas and the North-West Frontier", published in The Journal of Strategic Studies (December 1983), a review of British attitudes to gas and "frontier difficulties".

Whatever the wrangling over the use of 